\title{
Larvicidal Activity of Native Plant Extracts From the Araripe National Forest on Aedes aegypti
}

\author{
Francisco R. de Azevedo ${ }^{1}$, Glauber C. Maciel ${ }^{1}$, Gilberto B. Oliveira e Silva ${ }^{1}$, Francisco de O. Mesquita $^{1}$ \\ \& Antonio C. Leite Alves ${ }^{2}$ \\ ${ }^{1}$ Department of Agrarian Sciences and Biodiversity, Federal University of Cariri, Crato, CE, Brazil \\ ${ }^{2}$ Department of Plant Science, Federal University of Viçosa, Viçosa, Minas Gerais, Brazil \\ Correspondence: Francisco R. de Azevedo II, Department of Agrarian Sciences and Biodiversity, Federal \\ University of Cariri, Crato, CEP: 63.133-520, CE, Brazil. Tel: 55-889-9950-4498. E-mail: \\ roberto.azevedo@ufca.edu.br
}

Received: January 31, 2019

Accepted: March 3, 2019 Online Published: May 31, 2019

doi:10.5539/jas.v11n7p105

URL: https://doi.org/10.5539/jas.v11n7p105

The research was financed by the National Council for Technological Development Scientific (CNPq) and Higher Education Personnel Coordination (CAPES).

\begin{abstract}
Aiming to verify the insecticidal potential of 16 native plants from the Araripe National Forest (ANFO) on L3 Aedes aegypti larvae in laboratory conditions, were researches performed in controlled conditions of temperature, air relative humidity and photophase, in a type B.O.D. climatized chamber, executed in period from August/2016 to May/2017. The adopted experimental design was completely randomized, represented by ethanolic extracts obtained from 16 native plants, besides the witness without application and with pyriproxyfen as chemical insecticide, conducted with four replicates in each plant extract. The application of the extracts was performed only once, and at 24, 48 and 72 hours, after the infestation, was determined the effects of the extracts on larval mortality. The extracts of Amargoso, oiltree, Lacre, Cajui, Louro smelling, Field Rosemary, Murici truthful, Janaguba and laranjinha provoke mortality above of $90 \%$ to the larvae of Aedes aegypti after three days of exposure, in the dose of $50 \mathrm{~mL}$ of the extracts. After 24 hours of exposure, the ethanolic extracts from barks and leaves of Field Rosemary and of laranjinha killed all the larvae. On the other hand, the extracts with higher larvicide potential were evaluated at different doses (i.e., $12.5,25$, and $50 \mathrm{~mL} / \mathrm{L}$ ) in a $9 \times 3$ factorial scheme, with four replicates. The ethanolic extract of the leaves of Louro smelling is the most efficient, because in any dosage it eliminates all the larvae of Aedes aegypti, thus demonstrating to be an excellent vegetable larvicide in the control of this vector after three days of exposure, whereas the bark extract of the oil tree is the least effective. The alkaloids and flavonoids are present in the leaves of the Louro smelling.
\end{abstract}

Keywords: vegetables insecticides, biotechnology, dengue

\section{Introduction}

The Araripe National Forest (ANFO) is located in the Araripe Plateau, South of the Ceara state, being the first National Forest created in Brazil, with an area of 97.019.320 acres, presenting a tabular relief, varying from 760 to 920 meters, yearly average rainfall of $1.000 \mathrm{~mm}$ and temperature varying from 15 to $25^{\circ} \mathrm{C}$, covering part of the municipalities of Crato, Barbalha, Jardim and Santana of Cariri (IBAMA, 2010).

Due to its location and biodiversity of native plants, this area presents a great importance due to the ecological functions, presenting vegetation of the Cerrado, Caatinga and Atlantic Forest biomes, and areas of transition phytophysiognomies between the two extremes (Ceara, 2018).

The Aedes aegypti is a species of international interest for its ability in transmitting to humans four important arbovirus diseases: yellow fever, dengue, Zika and Chikungunya. The last one, recently, has been spreading to all continents (Lima \& Camara, 2018).

This vector of epidemiological importance in the Americas (Kay et al., 2010), found a favorable climate and propitious conditions to its rapid expansion in disorderly-created cities, with deficient water supply and poor urban 
cleansing. Added to these factors are the utilization of disposable recipients, which serve as artificial breeders for the mosquito (Heintze, Garrido, \& Kroeger, 2007; Sakthivadivel \& Daniel, 2008).

In Brazil, the mosquito is distributed throughout the entire country, with register of the circulation of the four serotypes of dengue virus (DENV), a situation which raised the risk of occurrence of the four severe manifestations of the disease, deaths and lethality (Ballenger-Browning \& Elder, 2009).

In spite of the advancements of the control centers and the researches, there is still no exist efficient preventive vaccine against the dengue. In the same manner, no etiological therapy or effective chemoprophylaxis are available. One of the main effective measures in the action against dengue consists in vector control, an action of collective responsibility, which demands the effort of the whole society (Câmara, Theophilo, \& Santos, 2007), but several technologies have been developed as alternatives in the control of this vector as selective monitoring of infestation, social measures, dispersion of chemical insecticides, new biological control agents and molecular techniques for population control of mosquitoes, however, the technologies in development demand evaluation of the effectiveness, feasibility and costs for implementation as complementary strategies to the actions already advocated by the National Dengue Control Program. Therefore, the integration of different compatible and effective vector control strategies, considering available technologies and regional characteristics, seems to be a viable method to try to reduce mosquito infestation and the incidence of arboviruses transmitted by them (Zara et al., 2016).

There are several researches with native and introduced plants in Brazil with insecticidal potential of the larvae from A. aegypti, such as Copaifera reticulata Ducke (Geris et al., 2008); Magonia pubescens Saint Hill (Arruda, Cavasin, and Silva (2008), Jatropha curcas L., Pedilanthus tithymaloides Poit, Phyllanthus amarus Schum, Euphorbia hirta Linn and Euphorbia tirucalli Linn (Rahuman et al., 2008), Persea americana Mill (Carvalho et al., 2011), Annona coriacea Mart (Dill, Pereira, \& Costa, 2012), Neoregelia compacta (Mez) and Aechmea fasciata (Lindley) (Guimarães et al., 2013), Piper aduncum Linn (Oliveira et al., 2013), Eugenia jambolana Lam (Sobral-Souza et al., 2013) and C. reticulata (Valotto et al., 2014).

Botanical products such as plant extracts and their proven insecticidal effects through scientific research have a wide range of active ingredients in their metabolism. These in turn act synergistically, thus being able to attract or repel insects. Therefore, due to these intrinsic characteristics, they can be used in integrated management systems of this vector, as one of the alternatives directed to the control and monitoring of populations of these insects (Navarro-Silva, Marques, \& Duque, 2009).

Generally, the insecticidal activity was attributed to the secondary metabolites of the plants. Indeed, the secondary metabolism is utilized by the plants as protection against the insects, arthropods and other phytophagous microorganisms (Belchior et al., 2012). Therefore, the secondary metabolites are natural candidates for the discovery of new products that might be utilized in insect control.

Substances synthesized in the secondary metabolism of the plants present biological action directly against agents attack or plants resistance induction, due to elicitors characteristics present in the active principles of the plants in the Araripe National Forest. The production of these chemical components has as the function to protect the plants against herbivores, pathogen attack, as well as benefiting them in competition with other vegetables (Silva et al., 2010; Vinale et al., 2014).

Some studies were already performed with extracts of native plants from the ANFO, with medical purposes (Pereira et al., 2014). However, works performed in the Cariri, related to the insecticide potential of these plants in the control of vectors are incipient. Those that exist are work with Drosophila melanogaster Linn (Sobral-Souza et al., 2013; Pinho et al., 2014) and with Trypanossoma cruzi and Leishmania brasiliensis Viannia (Leite et al., 2013). Therefore, the aim of this work was to evaluate the larvicidal potential of the ethanolic extracts of barks and leaves of native plants from the Araripe National Forest, according to Table 1 below, on the A. aegypti.

These plant species have been chosen to be studied as candidates for botanical larvicides because they have been widely used by Cariri family farmers and communities around the forest that use them for medicinal purposes to control some diseases.

\section{Materials and Methods}

\subsection{Plant Selection and Extraction Plant Selection}

Scientific literature queries and previous visits to the outskirts of the Araripe National Forest (ANFO) were performed in order to elaborate a list of the possible species with insecticidal potential on the larvae of the $A$. aegypti mosquito (Table 1). 
Table 1. Species of native plants found in the ANFO and the respective parts utilized in the experiments with ethanolic extracts

\begin{tabular}{llll}
\hline Common name & Scientific name & Family & Utilized part \\
\hline Praiba & Simarouba amara Aubl. & Simaroubaceae & Bark \\
Earth pau & Qualea parviflora Mart. & Vochysiaceae & Bark \\
Candeeiro & Vanillosmopsis arborea Baker & Asteraceae & Bark \\
Alecrim of field & Baccharis dracunculifolia DC. & Asteraceae & Bark and Leaf \\
Oil's tree & Copaifera langsdorffi Desf. & Fabaceae & Bark and Leaf \\
Lacre & Visenya sp. & Sterculiaceae & Leaf \\
Cajui & Anacardium humile Saint Hill & Anacardiaceae & Leaf \\
Louro smelling & Ocotea sp. & Lauraceae & Leaf \\
Faveira & Dimorphandra gardineriana Tehl & Leguminosae & Bark \\
Amargoso & Andira vermifuga Mart. & Leguminosae & Leaf \\
Amescla & Protium heptaphyllum March & Burseraceae & Bark \\
Maniçoba & Manihot sp. & Euphorbiaceae & Bark \\
Visgueiro & Parkia platycephala Benth & Mimosaceae & Bark \\
Janaguba & Himatanthus drasticus Mart. & Apocynaceae & Bark and Leaf \\
Murici truthful & Byrsonimasericea DC. & Malpighiaceae & Bark \\
Larajinha of bush & Xanthoxylum gardneri Engl. & Rutaceae & Bark and Leaf \\
\hline
\end{tabular}

Note. The number of plants and extracts depended of the epoch of occurrence, and, therefore, throughout the ten months of research, were tested several parts of these plants.

Selected plants were collected from the Araripe National Forest (ANFO) on February 24, April 28, June 30, and August 31, 2017 and separated into bark and leaves. Then, the parts of the plants were dried in a forced ventilation hothouse at $40{ }^{\circ} \mathrm{C}$, and grinded with a domestic blender, obtaining a dry powder. The plant extracts were obtained following the methodology adapted from Silva et al. (2017), through of the addition of $500 \mathrm{~g}$ of the powder with $1.500 \mathrm{~mL}$ of ethanol solvent. Following the methodology adapted from Carvalho et al. (2011), this mixture remained during 72 hours at ambient temperature and in the absence of light and; afterwards, the suspension was filtered with a cloth strainer mesh and separated, obtaining the crude ethanolic extract, which was immediately utilized in the study.

\subsection{Traps System}

For the collection of the mosquito eggs, 100 craft traps (oviposition traps) were installed in strategic spots, that is, those with known dengue transmission and presence of vector outbreaks. The oviposition trap was made utilizing a small dark vase for attraction of the female-vector, in which, was introduced about from $300 \mathrm{~mL}$ of water obtained from faucet of the municipal supply system, and a wood pallet of $10 \times 3 \mathrm{~cm}$ of porous texture for the fixation of the eggs.

The traps remained installed in the residencies per a period of five days, after which, the material was collected and taken at the Agricultural Entomology Laboratory of the FUCA, in the Center of Agricultural and Biodiversity Sciences (CCBS), of the Federal University of Cariri (FUCA), in the county of Crato, for the obtaining of the larvae. Afterwards, the identification of the insect was performed through morphological observations of the larvae and mounting of adults on lamina, based on the identification keys elaborated by Forattini (2002).

\subsection{Experimental Design}

The larvicide experiments were conducted under controlled conditions, at a mean temperature of $25 \pm 1{ }^{\circ} \mathrm{C}$, photophase of 12 hours in a type B.O.D. (Biochemical Oxygen Demand). Climatized chamber, being with the air relative humidity monitored by thermo-hygrometer and maintained at $70 \pm 10 \%$, from august $/ 2016$ to may/2017, being the collections of eggs and the obtaining of the larvaes realized weekly during the period in which the research was conducted.

3rd instar larvae (L3) were used and were placed in coffe cups with the capacity of $50 \mathrm{~mL}$, and in each replicate were put 10 live larvaes. It was used $50 \mathrm{~mL}$ of each crude extract per liter of water, since, in works with essential oils, usually, are utilized 1 to $5 \%$ per liter of water. Moreover, the chemical insecticide pyriproxyfen was used as positive control at the recommended dose by the manufacturer (i.e., $0.01 \mathrm{~g} / \mathrm{L}$ ). Conversely, distilled wated was used as negative control. 
The extracts were put in $1 \mathrm{~L}$ beakers containing distilled water, agitated with glass stick and, afterwards, was added $50 \mathrm{~mL}$ of the solution (extract/pyriproxyfen+water) in each little cup. The evaluations were realized at 24, 48 and 72 hours after the exposure of the larvaes, and were considered dead those, which did not react to the mechanical stimulation of a tweezers or a brush. The extracts that caused a mortality equal or superior to $90 \%$, were subjected to a new evaluation in smaller concentrations.

To evaluate the best concentration of the extracts, the completely randomized design (CRD) was adopted, in a $9 \times$ 3 factorial scheme, represented by the nine best extracts obtained and the dosages inferior to $50 \mathrm{~mL}$, doubled, being $12.5 ; 25$ and $50 \mathrm{~mL} / \mathrm{L}$ of water, conducted with four replicates per each extract and dosage. Were utilized 3rd instar larvae (L3), rather than 4rd instar larvae (L4) because they could become pupae during the conduction of the experiment because it is the last larval stage, in the same coffee cups-little utilized in the first test, and in each replicate 10 live larvae were also exposed. The evaluation was performed three days after the exposure of the larvae, and were considered dead those which did not react to the mechanical stimulation of tweezers or a brush.

\subsection{Phytochemical Screening}

To perform a preliminary phytochemical study of Louro smelling extract, initially, the dry ethanolic extract of the leaves was obtained through evaporation under reduced pressure. Following that, $200 \mathrm{mg}$ of the dry ethanolic extract were added in test tubes. The phytochemical study for the identification of the secondary metabolites was based in the methodology of Kokate, Purohit, and Gokhale (2008). The phytochemical tests were performed for the identification of alkaloids, phenolics in general, flavonoids, tannins, triterpenes, steroids and saponins.

The analysis was carried out in the Chemistry Laboratory of the Federal Rural University of Pernambuco, Serra Talhada Academic Unit, using 10 grams of the dried and crushed extract. This was placed into an Erlenmeyer flask and suspended with distilled water to the $100 \mathrm{~mL}$ mark of the flask. The mixture was stirred for $30 \mathrm{~min}$ and then collected by simple filtration with cotton. Into eight test tubes were added $3 \mathrm{~mL}$ each of the aqueous extract filtered as follows:

Tube 1: Tannins - 3 drops of $2 \%$ gelatin solution saturated with $\mathrm{NaCl}$ were added and there was no precipitate.

Tube 2: Saponins - the tube was shaken vertically for $30 \mathrm{~min}$ and after $5 \mathrm{~min}$ the foam persisted.

Tube 3: Triterpenes-Extraction was performed with $\mathrm{CHCl} \mathrm{3.} \mathrm{The} \mathrm{organic} \mathrm{phase} \mathrm{was} \mathrm{separated} \mathrm{from} \mathrm{the}$ aqueous phase slowly, three drops of sulfuric acid. There was no change in color;

Tube 4: Steroids-Extraction was performed with $\mathrm{CHCl}$ 3. The organic phase separated from the aqueous phase was added $1 \mathrm{~mL}$ of acetic anhydride and slowly three drops of sulfuric acid. There was no change in color.

Tube 5: Phenols-3 drops of 3\% FeCl 3 solution were added. A dark-colored top ring was formed.

Tube 6: Flavonoids - $\mathrm{Mg}$ shavings were added and then five drops of $\mathrm{HCl}$ slowly. Formation of dark solution.

Tube 7: Alkaloids - three drops of Dragendorff's reagent were added. An orange precipitate was formed.

Tube 8: White (reference).

\subsection{Statistical Analysis}

The results were subjected to analysis of variance by the F test, and the means were compared by the Tukey's test $(\mathrm{p}<0.05)$. For the processing of the data, was utilized the free version of the SISVAR 5.6 software, Build 86-DEX-UFL Alivre (Ferreira, 2011).

\section{Results and Discussion}

Out of the 16 evaluated plant species of the Araripe National Forest over the A. aegypti, nine caused larval mortality equal or superior to $90 \%$ (Table 2), and in the search for better alternatives in the control of Dengue, the utilization of these 9 plants is a viable option. This alternative has been highly researched in the last decades, mainly due to its lower impact to human health and to the environment, besides representing a method of easy obtaining. Medicinal plants are utilized throughout the world for many years, with wide utilization in agriculture as botanical insecticides (Bueno \& Carvalho, 2010; Carvalho et al., 2011).

After 24 hours of exposure, the leaf extract of the Louro smelling and the bark extracts of the alecrim and laranjinha caused $100 \%$ larval mortality, not statically differing from the leaf extracts of the amargoso or the bark extracts of the Oil's tree and the janaguba. Geris et al. (2008) tested the Oil's tree oil against larvae of A. aegypti, which demonstrated an excellent response, reaching an average of $90 \%$ larval mortality in the first day of treatment. 
Similarly, Oliveira et al. (2013) verified that the concentration of $1.000 \mathrm{ppm}$ of the Piper aduncum L. extract, caused $100 \%$ mortality in the larvae of this vector at $72 \mathrm{~h}$. Valoto et al. (2014) also verified that the 3- $\beta$-acetoxylabdan-8(17)-13-dien-15-oic acid, in the dose of $9 \mathrm{ppm}$, extracted from the medicinal plant Copaifera reticulata Ducke, a species of the same genus of the Oil's tree found in the ANFO, caused the death of larvae by midgut cell destruction, through the cytoplasmic vacuolization, cell and nuclear hypertrophy, brush border degeneration, apical vesicle formation with releasing of cytoplasmatic content, epithelium stratification and folding of the peritrophic matrix; however, in the present research, no were did or performed histological studies.

Table 2. Average number of dead larvae \pm SE and mortality efficiency in percentage of 3rd instar Aedes aegypti larvae subjected to different ethanolic extracts of native plants from the Araripe National Forest in the dose of 50 $\mathrm{mL} / \mathrm{L}$, and pyriproxyfen in the dosage of $0.01 \mathrm{~g} / \mathrm{L}$, at three exposure times

\begin{tabular}{|c|c|c|c|c|}
\hline \multirow{2}{*}{ Treatments } & \multicolumn{3}{|c|}{ Exposure time } & \multirow{2}{*}{ Efficiency } \\
\hline & $24 \mathrm{~h}$ & $48 \mathrm{~h}$ & $72 \mathrm{~h}$ & \\
\hline Distilled water & $0.3^{1} \pm 0.3 \mathrm{e}$ & $0.3 \pm 0.3 \mathrm{ef}$ & $0.5 \pm 0.5 \mathrm{a}$ & 0 \\
\hline Amargoso (Leaf) & $6.8 \pm 0.6 \mathrm{ab}$ & $3.3 \pm 0.6$ abcdef & $0 \pm 0 \mathrm{a}$ & 100 \\
\hline Praiba (Bark) & $1 \pm 0.6 \mathrm{de}$ & $6.5 \pm 1.2 \mathrm{ab}$ & $1.5 \pm 0.9 \mathrm{a}$ & 88.9 \\
\hline Earth pau (Bark) & $0 \pm 0 \mathrm{e}$ & $0.3 \pm 0.3 \mathrm{ef}$ & $1.3 \pm 1.3 \mathrm{a}$ & 5.6 \\
\hline Candeiro (Bark) & $0 \pm 0$ e & $5.5 \pm 1.7 \mathrm{abcd}$ & $0.5 \pm 0.3 \mathrm{a}$ & 55.6 \\
\hline Oil's tree (Leaf) & $1.3 \pm 0.8 \mathrm{de}$ & $8 \pm 0.7 \mathrm{a}$ & $0 \pm 0 \mathrm{a}$ & 91.7 \\
\hline Lacre (Leaf) & $3.8 \pm 0.6 \mathrm{bc}$ & $6 \pm 0.8 \mathrm{abc}$ & $0.3 \pm 0.3 \mathrm{a}$ & 100 \\
\hline Cajuí (Leaf) & $0.3 \pm 0.3 \mathrm{e}$ & $7.3 \pm 1 \mathrm{ab}$ & $1.8 \pm 0.6 \mathrm{a}$ & 91.7 \\
\hline Louro smelling (Leaf) & $10 \pm 0 \mathrm{a}$ & $0 \pm 0 \mathrm{f}$ & $0 \pm 0 \mathrm{a}$ & 100 \\
\hline Oil's tree (Bark) & $5.8 \pm 1.3 \mathrm{ab}$ & $0.5 \pm 0.3 \mathrm{ef}$ & $0.3 \pm 0.3 \mathrm{a}$ & 61.11 \\
\hline Faveira (Bark) & $2.8 \pm 1$ bcde & $2.8 \pm 1$ bcdef & $1 \pm 0.7 \mathrm{a}$ & 61.11 \\
\hline Amescla (Bark) & $4 \pm 0.4 \mathrm{bc}$ & $2.3 \pm 0.5$ bcdef & $0.5 \pm 0.5 \mathrm{a}$ & 63.9 \\
\hline Maniçoba (Bark) & $4.3 \pm 1.2 \mathrm{bc}$ & $1.3 \pm 0.5 \mathrm{def}$ & $0 \pm 0 \mathrm{a}$ & 50 \\
\hline Alecrim (*) & $10 \pm 0 \mathrm{a}$ & $0 \pm 0 \mathrm{f}$ & $0 \pm 0 \mathrm{a}$ & 100 \\
\hline Visgueiro (Bark) & $2.8 \pm 1.1$ bcde & $4.3 \pm 1.6$ abcde & $0.8 \pm 0.5 \mathrm{a}$ & 75 \\
\hline Janaguba (Leaf) & $4.5 \pm 1 \mathrm{abc}$ & $3.8 \pm 1.5$ abcdef & $0.3 \pm 0.3 \mathrm{a}$ & 83.3 \\
\hline Murici truthful (Bark) & $3.3 \pm 1.7$ bcde & $5 \pm 1.4 \mathrm{abcd}$ & $1.3 \pm 0.6 \mathrm{a}$ & 94.4 \\
\hline Janaguba (Bark) & $6.5 \pm 1.2 \mathrm{ab}$ & $1.8 \pm 0.9 \mathrm{cdef}$ & $1.3 \pm 0.6 \mathrm{a}$ & 94.4 \\
\hline Laranjinha (') & $10 \pm 0 \mathrm{a}$ & $0 \pm 0 \mathrm{f}$ & $0 \pm 0 \mathrm{a}$ & 100 \\
\hline Pyriproxyfen & $1.5 \pm 0.29 \mathrm{cde}$ & $2.0 \pm 0.58 \mathrm{cdef}$ & $1.50 \pm 0.29 \mathrm{a}$ & 41.2 \\
\hline C.V. $(\%)$ & 19.09 & 23.03 & 26.79 & - \\
\hline
\end{tabular}

Note. ${ }^{1}$ Means followed by the same letter in the columns are not significantly different by Tukey's test at $5 \%$ probability*(Bark and Leaf). $\mathrm{SE}=$ Standard Error.

Most of the tested ethanolic extracts of native plants from the Araripe National Forest presented larvicidal activity against the $A$. aegypti (Table 2), considering the total efficiency of the tree exposure periods, varying from 50 to $100 \%$ mortality, except for the bark extract of the Earth pau, which caused only $5.6 \%$ mortality, whereas the pyriproxyfen growth regulator reached $41.2 \%$.

The pyriproxyfen is not a product, which directly kills the mosquito larvae, but it interrupts the normal development process of the insect in the 4rth larval instar for the beginning of the pupal stage, leading to pupal mortality and preventing the emergence of adult mosquitoes. The pupal and larval stages of 4th instar are the most susceptible, but, in the present research, 3rd instar larvae were utilized. Although it is yet possible to verify larvae after the application of the SumiLarv ${ }^{\circledR}$, these usually die in the pupa/adult stage, thus preventing the appearing of adult mosquitoes, what was observed in the present research.

Resende and Gama (2016), when applying the pyriproxyfen in water tanks (45 liters), glass flasks (5 liters) and plastic buckets (20 liters), in the control of this vector, observed that the persistence was of 45 days and 90 days for the final concentration of 0.01 and $0.05 \mathrm{ppm}$ of pyriproxyfen, respectively, and that the pupal mortality was significantly higher than the larval and adult mortality for all tested recipients and concentrations. 
One of the least effective extracts in this exposure time was that obtained from the leaves of cajui, with only $0.3 \%$ mortality, not statistically differing from the distilled water, but showed high larvicidal activity at 48 hours. Porto et al. (2008) also did not verify a toxic effect of the ethanolic fraction of the leaves of this species over this mosquito vector.

At 48 hours of exposure, there was higher mortality when the larvae were subjected to the bark extracts of the Praiba and to the leaf extracts of the Oil's tree, lacre and cajuí. In this same exposure time, Barreto et al. (2006), observed that the crude ethanolic extract of the fruit husk of the soapberry (Sapindus saponaria L.) causes total or partial destruction of epithelial cells, high vacuolization, hypersecretion of the epithelial cells and paving of the midgut epithelium in the larvae of this vector.

When utilizing the ethanolic extract of the same plant species, Arruda, Cavasin, and Silva (2008), observed that the morphological alterations started after four hours of treatment, and included the loss of mitochondrial crests and the thickening of the peritrophic matrix. With the increase in the exposure time, new ultra-structural alterations were evidenced, highlighting the complete destruction of mitochondria, cytoplasmic vacuolization, loss, reduction or disruption of the microvilli and nuclear alterations.

At 72 hours, all extracts were not statistically different within each other and the witnesses, demonstrating that in the third day of exposure. Therefore, the highest larval mortalities occurred at 24 and 48 hours of exposure, being more efficient at 24 hours for some of the evaluated plants.

Guirado and Bicudo (2009), when utilizing coffee grounds, which contain caffeine, in the control of this insect, reported that this vegetable by-product, in the dose of 1.000 ppm, causes $100 \%$ mortality after 24 to 48 hours of exposure, presenting persistence in the environment for 7 months. Bansal et al. (2012) observed that at 24 and 48 hours, it was necessary to apply 63.2 and $128.10 \mathrm{mg}$ of the extract of fresh leaves of algarroba (Prosopis juliflora) respectively, in order to cause $90 \%$ mortality.

According to Guimarães et al. (2013), the highest efficiency of the crude extracts of ethyl acetate of Neoregelia compacta (Mez) and Aechmea fasciata (Lindley) over the L3 instar of A. aegypti is obtained with the concentration of de $200 \mu \mathrm{g} \mathrm{mL}^{-1}$, eliminating the larvae in less than a day, and consequently preventing its growth.

Beserra et al. (2014), observing positive results obtained with the larvicidal use of leaf and bark extracts of Jatropha curcas over $A$. aegypti, noticed that the action of the insecticide was significant over the $3^{\text {rd }}$ instar larvae of this disease-vector insect.

It is noted, therefore, that the most efficient ethanolic extracts were obtained from the leaves of amargoso, lacre, and Louro smelling, as well as the bark and leaf extracts of alecrim of field and laranjinha, which caused 100\% mortality after three cumulative days of exposure. In a concentration of $100 \mathrm{ppm}$ of the extract of Annona coriacea Mart., Dill, Pereira, and Costa (2012) observed a residual effect of $100 \%$ larval mortality during a period of 15 days

Of the nine plant extracts, analyzed in differents dosages varying from 12.50 to $50 \mathrm{~mL} / \mathrm{L}$ of ethanolic extracts extracted from different native plants (Table 3), only the leaf extract from the louro smelling, when compared with the remaining extracts, it obtained $100 \%$ of mortality. Already, the leaf extracts of alecrim of field, cajui and larajinha were the least effective when applied in concentrations smaller than $50 \mathrm{~mL} / \mathrm{L}$.

Table 3. Average number of dead larvae of Aedes aegypti subjected to nine ethanolic extracts of native plants from the Araripe National Forest, in three dosage $(\mathrm{mL} / \mathrm{L})$, after three days of exposure

\begin{tabular}{|c|c|c|c|c|c|c|c|c|c|}
\hline Dose & $A^{*}$ & $\mathrm{OT}^{*}$ & LS* & $\mathrm{JA}^{*}$ & LA* & LAJ* & MT* & $\mathrm{CA}^{*}$ & $\mathrm{AF}^{*}$ \\
\hline 12.5 & 7.0ABb & $5.7 \mathrm{BCb}$ & $10 \mathrm{Aa}$ & 3.0CDb & $6.7 \mathrm{ABa}$ & $0.2 \mathrm{Ec}$ & $2.2 \mathrm{~Eb}$ & $1.15 \mathrm{~Eb}$ & $0.0 \mathrm{~Eb}$ \\
\hline 25.0 & 9.5Aab & $9.50 \mathrm{Aa}$ & $10 \mathrm{Aa}$ & $4.0 \mathrm{Bb}$ & $6.8 \mathrm{ABa}$ & 3.2BCab & 2.2BCb & $2.0 \mathrm{BCb}$ & $0.2 \mathrm{Cab}$ \\
\hline 50.0 & 9.5Aab & $10.0 \mathrm{Aa}$ & $10 \mathrm{Aa}$ & $10 \mathrm{Aa}$ & $9.5 \mathrm{Aa}$ & $5.7 \mathrm{Ba}$ & $9.2 \mathrm{Aa}$ & $6.75 \mathrm{ABa}$ & 7.2Aba \\
\hline
\end{tabular}

Note. $\mathrm{A}^{*=}=$ Amargoso; $\mathrm{OT}^{*}=$ Oil's tree (leaves); LS*=Louro smelling; $\mathrm{JA}^{*}=$ Janaguba LA $*=$ Lacre; LAJ $*$ Laranjinha; $\mathrm{MT}^{*}=$ Murici truthful; $\mathrm{CA}^{*}=$ Cajui; $\mathrm{AF}^{*}=$ Alecrim of field; Means followed by the same uppercase letter in the column and lowercase in the line do not differ within each other by Tukey's test at 5\% probability.

The presented results are in accordance with the studies of Ndione et al. (2007), and Dua et al. (2009), when both evaluated the toxic effects of the oil extract of Azadirachta indica A. Juss, under several doses, against the larvae 
of this vector. These authors verified a mortality of approximately of 96 and $100 \%$ of the larval population only in the first day of exposure, reaching total mortality of the population after seven days of exposure. Nevertheless, from the lowest concentration $(2 \mathrm{mg} / \mathrm{L})$, a mortality under $50 \%$ of the population was obtained.

The ethanolic extracts of $A$. coriacea and $A$. mucosa (Jacq.) presented $100 \%$ of mortality in $0.1 \mathrm{mg} / \mathrm{mL}$. $A$. crassiflora Mart. presented mortality superior to $90 \%$ in $1.0 \mathrm{mg} / \mathrm{mL}$, in the methanolic crude extract, hexane and dichloromethane extracts and in the hexane fraction. The hydroalcoholic, ethyl acetate and chloroform fractions did not present insecticidal activity. In the species $A$. dioica Saint Hill and Cardiopetalum calophyllum, with crude extract, the mortality was inferior to $50 \%$. Therefore, A. crassiflora, A. coriaceae and A. mucosa, in methanol and hexane, are promising in the future development of biocides for the control of the dengue vector (Costa et al., 2013).

The data of this work are in agreement with the results presented by Silva et al. (2014), where these authors evidenced that the plant extracts demonstrated potentially promising with regard to the larval control of $A$. aegypti.

The phytochemical tests with the Dragendorff, Mayer's and Wagner's reactives were positive, pointing to the presence of alkaloids in the ethanolic extract of the louro smelling (Table 4). This result is in accordance with the literature, inasmuch as the aporphine alkaloids were identified in the species Ocotea sp. (Zanin \& Lordello, 2007). The presence of phenolic compounds in Ocotea sp. extracts was highlighted due to the capacity antioxidant. Thus, in the present research it is believed that the secondary metabolites that caused larvals mortality of $A$. aegypti were the alkaloids and the flavonoids, for being present in high concentrations in the ethanolic extract.

The test with gelatin's solution saturated with sodium chloride for the identification of the tannins was positive, and the test of flavonoids through of the Shinoda reaction was also positive. The test of the triterpenes class was positive, through the Salkowski reaction, but the test of the steroids was negative, through the Libermann-Burchard reaction and the foam test for saponins indenticatin was negative.

The extract of Louro smelling was chosen for phytochemical screening because it was the only one of the extracts tested that killed all A. aegypti larvae at all doses applied (Table 3).

Table 4. Phytochemical screening of the ethanolic extract of the leaves of Louro smelling (Ocotea sp.). Crato-CE, 2019

\begin{tabular}{llll}
\hline Secondary metabolites & Method & Result* & Observation \\
\hline Alkaloids & Dragendorff & +++ & Brown precipitate \\
& Wagner & ++ & Brown precipitate \\
& Mayer & + & Beige precipitate \\
Phenolic & $\mathrm{FeCl}_{3}$ & ++ & Gray precipitate \\
Tannins & Gelatin & ++ & White precipitate \\
Flavonoids & Shinoda & +++ & Red precipitate \\
Triterpenes & Salkowski & + & Red intense phase \\
Steroids & Libermann-Burchard & - & No significant change \\
Saponins & Foam & - & No formation of foam \\
\hline
\end{tabular}

Note. *(-) absence; $(+)$ low concentration; $(++)$ average concentration; $(+++)$ high concentration. Observation: The phytochemical testes were compared with the white (transparent green solution).

\section{Conclusions}

The Araripe National Forest presents a great potential with bioinsecticide plants of the tested plants, such as: the Amargoso, Oil's tree, Lacre, Cajuí, Louro smelling, Alecrim of field, Murici truthful, Janaguba and laranjinha cause mortality above $90 \%$ to the larvae of Aedes aegypti after three days of exposure in the dosage of $50 \mathrm{~mL}$ of the extracts.

After 24 hours of exposure, the ethanolic extracts from barks and leaves of the alecrim of field and the laranjinha kill all the larvae of Aedes aegypti in the dosage of $50 \mathrm{~mL}$. 
The ethanolic extract of the leaves from Louro smelling is the most efficient, because, in any dosage, it eliminates all the larvae of Aedes aegypti, thus demonstrating to be an excellent vegetable larvicide in the control of this vector after three days of exposure.

The alkaloids and flavonoids are present in high concentrations in the leaves of the Louro smelling.

The bark extract of the Earth pau is the least effective in the control of Aedes aegypti even after three days of exposure.

\section{References}

Arruda, W., Cavasin, G. M., \& Silva, I. G. (2008). Estudo ultraestrutura do efeito da toxicidade do extrato da Magonia pubescens (st. hil.) no mesêntero de larvas de Aedes aegypti (L.) (Diptera: Culicidae). Revista de Patologia Tropical, 37(3), 255-267. https://portais.ufg.br/up/63/o/2008_37_3_255_267.pdf

Ballenger-Browning, K., \& Elder, J. P. (2009). Multi-modal Aedes aegypti mosquito reduction interventions and dengue fever prevention. Tropical Medicine and International Health, 14(12), 1542-1551. https://doi.org/ $10.1111 / \mathrm{j} .1365-3156.2009 .02396 . x$

Bansal, S. K., Singh, K. V., Sharma, S., \& Sherwani, M. R. K. (2012). Laboratory observations on the larvicidal efficacy of three plant species against mosquito vectors of malaria, Dengue/Dengue Hemorrhagic Fever (DF/DHF) and lymphatic filariasis in the semi-arid desert. Journal of Environmental Biology, 33(1), 617-621.

Barreto, C. F., Cavasin, G. M., Silva, H. H. G., \& Silva, I. G. (2006). Estudo das alterações morfo-histológicas em larvas de Aedes aegypti (Diptera, Culicidae) submetidas ao extrato bruto etanólico de Sapindus saponária Lin (Sapindaceae). Revista de Patologia Tropical, 35(1), 37-57.

Beserra, F. P., Aguiar, R. W. S., Carvalho, E. E. N., Borges, J. C. M., \& Vale, B. N. (2014). Jatropha curcas L. (Euphorbiáceae) como novo bioinseticida: análise fitoquímica preliminar e atividade larvicida contra Aedes aegypti (Diptera: culicidae). Revista Amazônia Science \& Health, 2(3), 17-25.

Belchior, C., Del-Claro, K., \& Oliveira, P. S. (2012). Seasonal patterns in the foraging ecology of the harvester ant Pogonomyrmex naegelli (Formicidae, Myrmicidae) in a Neotropical savanna: Daily rhythms, shirt in granivory, and homerage. Arthropod-Plant Interact, 6(4), 571-582. https://doi.org/10.1007/s11829-012 $-9208-1$

Bueno, V. S., \& Andrade, C. F. S. (2010). Avaliação Preliminar de Óleos Essencias de Plantas como Repelentes para Aedes albopictus (Skuse, 1894) (Diptera: Culicidae). Revista Brasileira de Plantas Medicinais, 12(2), 215-219. https://doi.org/10.1590/S1516-05722010000200014

Câmara, F. P., Theophilo, R. L. G., \& Santos, G. T. (2007). Estudo retrospectivo (histórico) da dengue no Brasil: características regionais e dinâmicas. Revista da Sociedade Brasileira de Medicina Tropical, 40(2), 192-196. https://doi.org/10.1590/S0037-86822007000200009

Carvalho, G. H. F., Silva, H. H. G., Cunha, L. C., \& Silva, I. G. (2011). Atividade inseticida do extrato bruto etanólico de Persea americana (Lauraceae) sobre larvas e pupas de Aedes aegypti (Diptera, Culicidae). Revista de patologia tropical, 40(4), 348-361.

Ceará. (2018). Perfil básico municipal do Crato-2018. Retrieved from http://www.ipece.ce.gov.br/publicacoes/ perfil_basico/pbm-2018/Crato.pdf

Costa, M. S., Pereira, M. J. B., Oliveira, S. S., Sousa-Junior, P. T., Dall'Oglio, E. L., \& Lves, T. C. (2013). Anonáceas provocam mortalidade em larvas de Aedes aegypti (Diptera: Culicidae). Revista Brasileira de Biociência, 11(2), 184-190.

Dill, E. M., Pereira, M. J. B., \& Costa, M. S. (2012). Efeito residual do extrato de Annona coriacea sobre Aedes aegypti. Arquivos do Instituto Biológico, 79(4), 595-601. https://doi.org/10.1590/S1808-1657201200 0400017

Dua, V. K., Pandey, A. C., Raghavendra, K., Gupta, A., Sharma, T., \& Dash, A. P. (2009). Larvicidal Activity of Neem Oil (Azadirachta indica) Formulation against Mosquitoes. Malaria Journal, 8(1), 1-6. https://doi.org/ 10.1186/1475-2875-8-124

Ferreira, D. F. S. (2011). A computer statistical analysis system. Ciência e Agrotecnologia, 35, 1039-1042. https://doi.org/10.1590/S1413-70542011000600001 
Forattini, O. P. (2002). Culicidologia médica: identificaçäo, biologia e epidemiologia (2nd ed., p. 864). São Paulo, EDUSP

Geris, R., Silva, I. G., Silva, H. H., Barison, A., Rodrigues-Filho, E., \& Ferreira A. G. (2008). Diterpenoids from Copaifera reticulata Ducke with larvicidal activity against Aedes aegypti (L.) (Diptera, Culicidae). Revista do Instituto de Medicina Tropical, 50(1), 25-28.

Guimarães, M. G. A., Martins, K. S., Carvalho, M. A., Kersten, V. A., Vieira, R. R., \& Maleck, M. Ação dos extratos de Neoregelia compacta (Mez) L.B. Smith e Aechmea fasciata (Lindley) Baker sobre as formas imaturas de Aedes (Stegomyia) aegypti. Revista Fitos, 8(2), 73-160.

Guirado, M. M., \& Bicudo, H. M. C. B. (2009). Alguns aspectos do controle populacional e da resistência a inseticidas em Aedes aegypti (Diptera, Culicidae). Bepa: Epidemiológica Paulista, 6(64), 5-14.

Heintze, C., Garrido, M. V., \& Kroeger. A. (2007). What do community-based dengue control programs achieve? A systematic review of published evaluations. Transactions of the Royal Society of Tropical Medicine and Hygiene, 101(4), 317-325. https://doi.org/10.1016/j.trstmh.2006.08.007

IBAMA. (2010). Áreas de Proteção Ambiental. Retrieved from http://www.ibama.gov.br

Kay, B. H., Tuyet-Hanh, T. T., Le, N. H., Quy, T. M., Nam, V. S., Hang, P. V., ... Ryan, P. A. (2010). Sustainability and cost of a community-based strategy against Aedes aegypti in Northern and Central Vietnam. Transactions of the Royal Society of Tropical Medicine and Hygiene, 82(5), 822-830. https://doi.org/ 10.4269/ajtmh.2010.09-0503

Kokate, C. K., Purohit, A. P., \& Gokhale, S. B. (2008). Pharmacognosy (42th ed., p. 635). Nirali Prakashan: Pune.

Lima, V. H. F., \& Camara, T. N. L. (2018). Natural vertical transmission of dengue virus in Aedes aegypti and Aedes albopictus: A systematic review. Parasites \& Vectors, 11(77), 2-8.

Leite, N. F., Sobral-Souza, C. E., Albuquerque, R. S., Brito, D. I. V., Lavor, A. K. L. S., Alencar, L. B. B., ... Coutinho, H. D. M. (2013). Atividade antiparasitária in vitro e citotóxica de cariofileno e eugenol contra Trypanossoma cruzi e Leishmania brasiliensis. Revista Cubana de Plantas Medicinales, 18(4), 522-528.

Navarro-Silva, M. A., Marques, F. A., \& Duque, J. E. L. (2009). Review of semiochemicals that mediate the oviposition of mosquitoes: A possible sustainable tool for the control and monitoring of Culicidae. Revista Brasileira de Entomologia, 53(1), 1-6. https://doi.org/10.1590/S0085-56262009000100002

Ndione, R. D., Faye, O., Ndlaye, M., Dieye, A., \& Afautou, J. M. (2007). Toxic effects of neem products (Azadirachta indica A. Juss) on Aedes aegypti Linnaeus 1762. African Journal of Biotechnology, 6(24), 2846-2854. https://doi.org/10.5897/AJB2007.000-2454

Oliveira, G. L., Cardoso, S. K., Lara Júnior, C. R., Vieira, T. M., Guimarâes, E. F., Figueiredo, L. S., ... Kaplan, M. A. C. (2013). Chemical study and larvicidal activity against Aedes aegypti of essential oil of Piper aduncum L. (Piperaceae). Anais da Academia Brasileira de Ciências, 85(4), 1227-1234. https://doi.org/ 10.1590/0001-3765201391011

Pereira, P. S., Barros, L. M., Brito, A. M., Duarte, A. E., \& Maia, A. J. (2014). Uso da Myracroduon urundeuva (lentisco) por los agricultores en el tratamiento de enfermedades. Revista Cubana de Plantas Medicinales, 19(1), 51-60.

Pinho, A. I., Wallau, G. L., Nunes, M. E. M., Leite, N. F., Tintinho, S. R., Cruz, L. C., ... Franco, J. L. (2014). Fumigant Activity of the Psidium guajava var. Pomifera (Myrtaceae) Essential Oil in Drosophila melanogaster by Means of Oxidative Stress. Oxidative Medicine and Cellular Longevity, 1, 1-8. https://doi.org/10.1155/2014/696785

Porto, K. R. A., Roel, A. R., Silva, M. M., Coelho, R. M., Scheleder, E. J. D., \& Jeller, A. H. (2008). Atividade larvicida do óleo de Anacardium humile Saint Hill sobre Aedes aegypti (Linnaeus, 1762) (Diptera, Culicidae). Revista da Sociedade Brasileira de Medicina Tropical, 41(6), 586-589. https://doi.org/10.1590/S003786822008000600008

Rahuman, A. A., Gopalakrishnan, G., Venkatesan, P., \& Geetha, K. (2008). Larvicidal activity of some Euphorbiaceae plant extracts against Aedes aegypti and Culex quinquefasciatus (Diptera: Culicidae). Parasitology Research, 102(5), 867-873. https://doi.org/10.1007/s00436-007-0839-6 
Sakthivadivel, M., \& Daniel, T. (2008). Evaluation of certain insecticidal plants for the control of vector mosquitoes Culex quinquefasciatus, Anopheles stephensi and Aedes aegypti. Applied Entomology and Zoology, 43(1), 57-63. https://doi.org/10.1303/aez.2008.57

Silva, M. L. C., Costa, R. S., Santana, A. S., \& Koblitz, M. G. B. (2010). Compostos fenólicos, carotenóides e atividade antioxidante em produtos vegetais. Semina: Ciências Agrárias, 31(3), 669-682. https://doi.org/ 10.5433/1679-0359.2010v31n3p669

Silva, S. L. C., Gualberto, S. A., Carvalho, K. S., \& Fries, D. D. (2014). Avaliação da atividade larvicida de extratos obtidos do caule de Croton linearifolius Mull. Arg. (Euphorbiaceae) sobre larvas de Aedes aegypti (Linnaeus, 1762) (Diptera: Culicidae). Revista Biotemas, 27(2), 79-85. https://doi.org/10.5007/2175-7925. 2014v27n2p79

Silva, T. I., Leite, A. C. A., Azevedo, F. R., Marco, C. A., Santos, H. R., \& Alves, W. S. (2017). Efeito larvicida de óleos essenciais de plantas medicinais sobre larvas de Aedes aegypti L. (Diptera: Culicidae). Revista verde de Agroecologia e Desenvolvimento Sustentável, 12(2), 256-260. https://doi.org/10.18378/rvads.v12i2.4672

Sobral-Souza, C. E., Leite, N. F., Cunha, F. A. B., Pinho, A. I., Albuquerque, R. S., Carneiro, J. N. P.,... Coutinho, H. D. M. (2013). Cytoprotective effect against mercury chloride and bioinsecticidal activity of Eugenia jambolana Lam. Arabic Journal Chemistry, 7(1), 165-170. https://doi.org/10.1016/j.arabjc.2013.10.003

Tafurt-García, G., Jiménez-Vidal, L. F., \& Calvo-Salamanca, A. M. (2015). Capacidade antioxidante e conteúdo de fenóis totais de Hyptis spp., P. heptaphyllum, T. panamensis, T. rhoifolia, e Ocotea sp. Revista Colombiana de Quimica, 44(2), 28-33. https://doi.org/10.15446/rev.colomb.quim.v44n2.55217

Valotto, C. F. B., Silva, H. H. G., Cavasim, G., \& Geris, R. (2014). Atividade larvicida do ácido 3- $\beta$-acetoxylabdan-8(17)-13-dien-15-óico isolado da planta medicinal Copaifera reticulata (Leguminosae) sobre Aedes aegypti (Diptera, Culicidae) evidenciada pelas alterações morfohistológicas. Revista de Patologia Tropical, 43(3), 375-384.

Vinale, F., Sivasithamparam, K., Ghisalberti, E. L., Woo, S. L., Nigro, M., Marra, R., ... Lorito, M. (2014). Trichoderma Secondary Metabolites Active on Plants and Fungal Pathogens. The Open Mycology Journal, 8(1), 127-139. https://doi.org/10.2174/1874437001408010127

Zanin, S. M. W., \& Lordello A. L. L. (2007). Alcalóides aporfinóides do gênero Ocotea (Lauraceae). Química Nova, 30(1), 92-98. https://doi.org/10.1590/S0100-40422007000100020

Zara, A. L. S. A., Santos, S.M., Fernandes-Oliveira, E. S., Carvalho, R. G., \& Coelho, G. E. (2016). Estratégias de controle do Aedes aegypti: Uma revisão. Epidemiologia e Serviçõs de Saude, 25(2), 391-404.

\section{Copyrights}

Copyright for this article is retained by the author(s), with first publication rights granted to the journal.

This is an open-access article distributed under the terms and conditions of the Creative Commons Attribution license (http://creativecommons.org/licenses/by/4.0/). 